\title{
Antonio Machado y la búsqueda del otro
}

\section{Armando LÓPEZ CASTRO}

Universidad de León

Uno de los temas característicos de la poesía contemporánea es la búsqueda de la identidad personal. En Los hijos del limo (1974), Octavio Paz propone como rasgo esencial de la poesía de nuestro tiempo la crítica o desaparición del sujeto poético, que deja de ser la voz del yo para buscarse en la voz del otro. Polaridades, máscaras y espejos pueblan la lírica del siglo XX, en un proceso de despersonalización que comienza con los poetas románticos (Así, para Keats, el poeta carece de identidad), se afianza en los simbolistas franceses ("Je est un autre", escribe Rimbaud a P. Demeny el 15 de mayo de 1871) y alcanza, a nivel hispánico, su expresión más reconocible en la lírica de Unamuno y Vallejo. En ambos, se da un diálogo del yo con el otro que lo constituye, fusión que se vislumbra, pero no se alcanza, en el poema "Yo y yo", de Juan Ramón Jiménez, perteneciente a Piedra y cielo (1919), donde el yo subjetivo se opone al tú trascendente, sin atreverse a dar el salto definitivo hacia el otro. Si Juan Ramón representa la "esencial homogeneidad del yo", Machado habla, por boca de su heterónimo Abel Martín, de la "esencial heterogeneidad del ser", de manera que la palabra solitaria de Machado, sobre todo a partir de las lecturas filosóficas en su retiro de Baeza (1912-1919), se revela cada vez más como canto solidario, como la otra voz, aquella que nos busca para nombrarnos ${ }^{1}$.

La trayectoria de Machado, tomada en su conjunto, ofrece una profunda coherencia, en la que se aprecia un movimiento de lo uno a lo otro. De acuerdo con el método dialéctico, Machado pasa del yo intimista de Soledades (1903) al tú objetivo de Campos de Castilla (1912), para llegar a una síntesis final, el inclusivo nosotros de Nuevas canciones (1924) y De un cancionero apócrifo (1924-1936), que deja superadas las dos fases anteriores. En la medida en que el comportamiento dialéctico de Machado encuentra su justificación en las filosofías fenomenológica y existencialista, difundidas en Europa tras la primera guerra mundial como superadoras del subjetivismo ideali-

${ }^{1}$ A nivel poético, el tema de la otredad ha sido analizado por A. CARREÑO en su estudio La dialéctica de la identidad en la poesía contemporánea, Madrid (Gredos) 1982. Desde el punto de vista filosófico-antropológico, véase el trabajo de P. LAÍN ENTRALGO, Teoría y realidad del otro, I, Madrid (Revista de Occidente) 1961, pp.99-115). 
zante y defendidas por Buber, Marcel, Bakhtin y Bergson como lector de Berkeley, es posible entender el principio dialógico, al que Machado llamó "la heterogeneidad del ser", como tensión polar del Yo con lo Otro, como efecto de una relación recíproca, donde lo Otro deja de ser algo extraño para convertirse en algo propio. En la unidad del poema, siempre la prelación la tiene lo Otro, lo que siento que me busca, me habla, o me busca para hablarme. Ante esa situación de inminencia, que nos abre a la posibilidad de la creación, todo poeta depone su propia voz y queda en una soledad receptiva, en una espera oyente. Hasta no ser Otro somos a medias. En este sentido, lo que hace el símbolo es dialogar con la mitad ausente, dejando aparecer lo Otro en la realidad del lenguaje. Machado comienza el peregrinaje de lo simbólico desde el inicio mismo de su escritura, instaurando la imaginación como verdadera realidad.

Ya en el aura intimista de Soledades (1903), el diálogo del poeta con la noche genera un intento de descubrir el secreto, el que las lágrimas y el dolor sean reales, aunque la búsqueda por el sueño resulte inútil ("Para escuchar tu queja de tus labios / yo te busqué en tu sueño, / y allí te vi vagando en un borroso / laberinto de espejos", XVI, vv.37-40), siendo el espejo, con su ambivalencia, expresión más que reflejo de la realidad esencial. De hecho, el desdoblamiento del yo poético responde a un deseo de totalidad, pues el Yo se siente completo sólo con lo Otro. La crisis del sujeto o "muerte del Yo", propia del pensamiento contemporáneo, sólo puede salvarse a través de la poesía, que nos aproxima a la otra voz, al "Nosotros" anónimo de la canción tradicional "Los cantos de los niños", cuyo estribillo ("confusa la historia / y clara la pena"), que al final se resuelve en el olvido revelador (borrada la historia, / contaba la pena"), concentra en sí mismo la materia de la vida, hecha de alegría y tristeza, mediante la imagen simbólica de "la fuente de agua y piedra", y muestra la emoción hecha canto después que lo anecdótico ha desaparecido. Con la síntesis de elementos contrarios, idéntica y distinta en sus sucesivas apariciones, Machado no sólo insiste en su actitud dialéctica frente a la creación poética, tanto más ambigua cuanto más precisa, sino también en el reconocimiento de la realidad, donde se esconde tal vez el secreto del Yo y del Otro. La construcción del poema sobre la analogía entre lo abstracto y lo concreto, entre la función aclarativa del símil y el valor connotativo de los adjetivos, pone de relieve el deseo de 
sentirse acogido por una ilusión de realidad, el Otro de sí en la espontaneidad del canto infantil, pero sin destruir el lenguaje ${ }^{2}$.

La creciente atención de Machado a lo Otro y a los Otros, ya visible en el poema "Retrato" de Campos de Castilla ("Hay en mis versos gotas de sangre jacobina, / pero mi verso brota de manantial sereno", vv.9-10), le lleva a salir de su intimismo simbolista y a dar a su discurso una tonalidad social. Si en las Soledades (1903-1907) buscaba Machado "los universales del sentimiento", ahora en Campos de Castilla (1907-1912), al alcanzar su madurez humana y poética, descubre que el sentimiento es una experiencia colectiva ("Mi sentimiento no es, en suma, exclusivamente mío, sino más bien nuestro. Sin salir de mí mismo, noto que en mi sentir vibran otros sentidos y que mi corazón canta siempre en coro, aunque su voz sea para mí la voz mejor timbrada. Que lo sea también para los demás, éste es el problema de la expresión lírica", nos dice el poeta sevillano en su ensayo "Problemas de la lírica", escrito en 1917). Para que tal sentimentalidad aflore poéticamente, es preciso borrar las fronteras entre el dentro y el fuera, entre el sueño y la realidad ("me habéis llegado al alma / ¿o acaso estabais en el fondo de ella?”, escuchamos en el poema "Campos de Soria"). La experiencia objetiva del sentir es lo que da unidad a poemas como "El Dios ibero", "Las encinas”, “Eres tú, Guadarrama" y "En abril, las aguas mil", escritos de 1907 a 1910 e incorporados después al conjunto de Campos de Castilla a partir de la edición de Poesías completas (1917). De todos ellos, tal vez sea el tercero uno de los más destacados en el tratamiento lírico del paisaje

\section{CIV}

¿Eres tú, Guadarrama, viejo amigo, la sierra gris y blanca,

\footnotetext{
${ }^{2}$ En su escrito "Para un estudio de la literatura española", con fecha 15 de junio de 1914 e incluido en Los complementarios, señala Machado: "Lo anecdótico, lo documental humano, no es poético por sí mismo. Tal era mi parecer de hace veinte años. En mi composición Los cantos de los niños, escrita el año 98 (publicada en 1904: Soledades), se proclama el derecho de la lírica a contar la pura emoción, borrando la totalidad de la historia humana. El libro Soledades fue el primer libro español del cual estaba íntegramente prohibido lo anecdótico. Coincidía yo anticipadamente con la estética novísima. Pero la coincidencia de mi propósito de entonces no iba más allá de esta abolición de lo anecdótico". Con el tiempo, Machado aprendería a integrar en el poema lo anecdótico y lo misterioso. Sobre este problema estético, Cf. A. GONZÁLEZ, "Identidad de contrarios en la poesía de Machado", Cuadernos Hispanoamericanos, $\mathrm{n}^{\circ}$. 304-307, Vol.I, pp.544-558.
} 


\title{
Armando López Castro
}

\author{
la sierra de mis tardes madrileñas \\ que yo veía en el azul pintada?
5 Por tus barrancos hondos y por tus cumbres agrias, mil Guadarramas y mil soles vienen, cabalgando conmigo, a tus entrañas.

Hay dos modos de presentar poéticamente el paisaje: traducirlo tal cual es en sí, sin interferir en él nuestro sentimiento, y evocarlo en función del estado anímico, de su recuerdo y nostalgia. De los dos hay abundantes ejemplos en la obra de Machado, pero el predominio del segundo sobre el primero, especialmente a partir de su estancia en Baeza, cuando evoca a su amada enterrada en El Espino, revela la necesidad de descubrir en la naturaleza la verdad oculta de nuestro ser. Sentida así, con la nostalgia del tiempo roto, la sierra madrileña pervive en la memoria como realidad vivida poéticamente. Todo el poema está articulado sobre el juego entre la naturaleza y la intimidad del poeta, de manera que el lenguaje evocativo, obtenido mediante los pronombres personales, el tiempo lento de las formas verbales en imperfecto ("veía") y gerundio ("cabalgando") y la serie de adjetivos caracterizadores ("viejo amigo", "la sierra gris y blanca", "Por tus barrancos hondos / y por tus cumbres agrias"), tiende a objetivar la experiencia, dotándola de universalidad ("mil Guadarramas y mil soles vienen"). En realidad, lo que el poema pretende es espiritualizar el paisaje, darle un sentido trascendente, de ahí que, en su evocación, retenga "el azul", color que ya desde Novalis se había convertido en símbolo de lo absoluto. Machado se siente a sí mismo en el paisaje y lo convierte en medio lírico por excelencia ${ }^{3}$.

Al comentar la aparición de Campos de Castilla, ya señaló Ortega, en julio de 1912, que el mejor acierto de Machado en la descripción del paisaje es su humanización. Gracias al paisaje como realidad vivida, a su vibración íntima, lo real se transforma en esencial. En el poema "La tierra de Alvargonzález", drama de la tierra y expresión de

\footnotetext{
${ }^{3}$ Para la visión del paisaje machadiano, tengo en cuenta los siguientes estudios: Aurora de ALBORNOZ, El paisaje en la poesía de Antonio Machado, Universidad de Puerto Rico, 1959; B. MOSTAZA, "El paisaje en la poesía de Antonio Machado", en Cuadernos Hispanoamericanos 11-12, 1949, 623-641; J.J. MARTÍN GONZÁLEZ, "Poesía y pintura en en paisaje castellano de Antonio Machado", en Homenaje a Machado, Universidad de Salamanca 1975, pp.179-193; y A. LÓPEZ CASTRO, "Antonio Machado: paisaje más allá del paisaje", en revista Huarte de San Juan. Filología y Didáctica de la Lengua 4, Universidad Pública de Navarra, pp.55-68.
} 
la tradición popular, la humanización del paisaje (“iOh tierras de Alvargonzález, / en el corazón de España, / tierras pobres, tierras tristes, / tan tristes que tienen alma!"), responde al deseo de fundir lo particular y lo general, de ver en el paisaje soriano la esencia de la tierra española ("Hermosa tierra de España", finaliza el poema "Orillas del Duero"). La contemplación del paisaje soriano le sirvió a Machado para salir de sí mismo y aproximarse al otro, para profundizar en el pasado nacional mediante el romance, que, en su doble función de cantar y contar, busca identificar lo individual y lo colectivo ("Si la poesía es, como yo creo, palabra en el tiempo, su metro más adecuado es el romance, que canta y cuenta, que ahonda constantemente la perspectiva del pasado, poniendo en serie temporal hechos, ideas, imágenes, al par que avanza, con su periódico martilleo, en el presente", dice Machado en su texto sobre Moreno Villa). Lejos de convertirse en una fórmula estereotipada, como sin duda acabó siendo en manos de Rivas y Zorrilla, el romance fue para Machado una forma dinámica de rendir homenaje a la tradición, que en su unidad trasciende al poeta y a la poesía misma, pues en toda influencia literaria hay una solidaridad con el lenguaje del otro o de los otros. Si lo que distingue a toda tradición es su impulso dinámico, su capacidad para incorporar y eliminar elementos de procedencia diversa, la continuidad expansiva del romance, con su fluidez musical y concisión expresiva, se revela como la forma más directa de ahondar en "lo elemental humano", de manifestar la sentimentalidad colectiva. En "La tierra de Alvargonzález", al igual que en Campos de Castilla, del que viene a ser su núcleo integrador, el lenguaje poético, formado en su propia intimidad y dicho con suficiente pobreza, no pertenece exclusivamente ni al yo ni al otro, sino al fondo común de la tierra de Soria, sus paisajes, sus costumbres y sus gentes, del que llega a ver las cosas incorporadas a su vivir y nos ofrece una interpretación poética de ellas ${ }^{4}$.

\footnotetext{
${ }^{4}$ El sentido de pobreza, tan presente en Campos de Castilla, cuyo título inicial iba a ser precisamente Tierras pobres, no pudiendo terminarlo Machado por la muerte de Leonor y su inmediata salida hacia Baeza, no es ajeno al lenguaje natural y sencillo con el que el poeta pretende universalizar sus vivencias. Respecto a la contemplación del paisaje soriano por Machado, cuya mirada se dirige a lo humano, José María VALVERDE, Antonio Machado, Madrid (Siglo XXI) 1978, $3^{\text {a }}$ ed., pp.93-94, ha señalado: "Pero, el lugar de quedarse en la estricta objetividad histórica de las cosas como quiso o fingió Rilke-, Antonio Machado vio en el paisaje también el alma colectiva y secular que le daba alma y sentido, y eso le llevaría hacia los otros, justificando e intensificando su tendencia a meditar sobre su propia visión, y sobre la visión del mundo en general".
} 


\section{Armando López Castro}

El contenido de lo poético escapa a toda identificación previa. La mirada poética, siempre en busca de un sentido trascendente, rebasa cualquier esquema preconcebido. Tal vez por eso, la poesía no es un género, sino una forma de visión. Los cinco años que Machado pasó en Soria orientaron su mirada "hacia lo esencial castellano", según nos dice en el Prólogo de Campos de Castilla, y la mirada del poeta, al recrearse en la visión directa de las cosas, se hace cada vez más cordial, incorporando a su sentir otros sentires. Para Machado, la poesía está obligada a ser la otra voz, la voz de los otros y de lo otro, aquella que deja oír en el poema el sentir y el pensar colectivos ("Yo, por ahora, no hago más que Folk-lore, autofolklore o folklore de mí mismo. Mi próximo libro será, en gran parte, de coplas que no pretenden imitar la manera popular -inimitable e insuperable, aunque otra cosa piensen los maestros de retórica-, sino coplas donde se contiene cuanto hay en mí de común con el alma que canta y piensa en el pueblo. Así creo yo continuar mi camino, sin cambiar de rumbo", dice Machado a Cipriano Rivas Cherif en carta del 17 de septiembre de 1920). El propósito que guía la escritura de Nuevas canciones (1924) es el equilibrio entre subjetividad y objetividad, la reconciliación como aceptación de la otredad que nos constituye, la elaboración de un discurso que deja de ser monólogo para convertirse en diálogo. Tales notas subyacen en las distintas partes del libro, aunque tal vez sea en los "Proverbios y cantares", que ya había llevado a cabo en Campos de Castilla, aunque bastante distintos del libro anterior, donde la realidad del "Otro" se afirma con mayor precisión. Dentro de su variedad, común por lo demás a todo el libro, la relación del yo con sus semejantes parece imponerse como núcleo de toda la serie, hasta el punto de llegar a constituir una poética de la otredad, basada en la recomposición de una nueva unidad. La experiencia de lo Otro culmina en la experiencia de la Unidad. Ser Otro es volver a ser original ${ }^{5}$.

Debido a la alteridad que lo habita, el Yo deviene oyente pasivo. Siendo la mirada del Otro un imperativo, implica, por parte del receptor, la obediencia como única audición posible. La obediencia o

\footnotetext{
${ }^{5}$ Para Machado, todavía inmerso en el subjetivismo de la estética romántica, el yo se realiza cuando se hace otro, cuando la palabra recupera su Unidad perdida. Refiriéndose a ella, señala O. PAZ, El arco y la lira, México (FCE) 1979, $5^{\mathrm{a}}$ reimpr., p.178: "La palabra poética es revelación de nuestra condición original porque por ella el hombre efectivamente se nombra otro, y así él es, al mismo tiempo, éste y aquél, él mismo y el otro". La tarea de conciliar proximidad y distancia, inmediatez y trascendencia, está reservada al lenguaje, cuya esencia, según afirma E. LÉVINAS, "es la relación con el prójimo", en su estudio Totalidad e infinito, Salamanca (Sígueme) 1977, pp.181-182.
} 
escucha del Yo le abre a la posibilidad de la creación, según se aprecia en el primer proverbio, que reviste ya un carácter programático

I

El ojo que ves no es

ojo porque tú lo veas,

es ojo porque te ve.

El poeta es un ser de la espera, de lo que está aún por manifestarse. En el acto creador, el Yo poético acoge la imagen del otro, le da voz. Como sucede en el mito de Narciso, que es una revelación del otro en la imagen de sí. En la mediación de la fuente o el espejo, símbolo que permite el deslizamiento del uno hacia el otro de sí, el sí mismo se descubre como otro y ambos quedan unificados en la visión. Por eso, en el proverbio IV, complementario del anterior, se dice: "Mas busca en tu espejo al otro, / al otro que va contigo". Fuente de la imagen o palabra originaria, sin que la unidad se rompa ${ }^{6}$.

Para ser, para que el Yo se realice en el Tú, es necesaria la conversión. Al llegar a la unidad de la conciencia, los contrarios se hacen complementarios. Entre el Yo y el Tú media el espejo, símbolo mágico que, en su duplicación de la realidad, nos abre a un mundo velado, al Otro desconocido. Sólo porque el Tú se torna presente en el Yo, surge la complementariedad, la totalidad de una relación vivida poéticamente, que será el núcleo del pensamiento de los apócrifos, su verdadera razón de ser

\section{XV}

Busca a tu complementario, que marcha siempre contigo y suele ser tu contrario.

Lo que se pone de manifiesto en este proverbio, donde por primera vez aparece la misteriosa palabra básica, es la relación de un encuentro originario, pues el Yo se hace Otro por su participación en la realidad. La reconciliación poética de los contrarios radica en lo más íntimo de la vida individual y sólo se entiende desde la experiencia de

${ }^{6}$ La visión negativa que Machado nos ofrece del mito de Narciso ("Todo narcisismo / es un vicio feo, / y ya viejo vicio", III), se debe a la falta de unidad, pues hasta no ser otro somos incompletos. Sobre la significación de este mito, véase J.A. VALENTE, "Pasmo de Narciso", en La piedra y el centro, Madrid (Taurus) 1983, pp.1718. 


\section{Armando López Castro}

la unidad en que todo poema consiste. La experiencia poética nos restituye la unidad de la conciencia, la realización del ser, de manera que, en la relación plena, el Tú abarca al Yo y lo sobrepasa

\section{XXXVI}

No es el yo fundamental eso que busca el poeta, sino el tú esencial.

La relación Yo-Tú implica una correlación de personalidad, una dialéctica de interioridad y trascendencia, que se expresa lingüísticamente. En esta relación lingüística, donde el Yo interior y el Tú externo se perciben como complementarios, radicaría la poética de la otre$d a d$, basada en un proceso simultáneo de alteridad, en el que la apertura del yo solipsista va unida al reconocimiento del otro. Bajo la experiencia de la alteridad, que suscita la tensión entre sujeto y objeto, asoma una vez más el enigma del pensamiento, donde se esconde tal vez el secreto del yo y del otro. En efecto, lo enigmático permanece arraigado en la otredad del "tú esencial" que, a modo de inminencia, soporta y sostiene el lenguaje. Pues lo poético viene de ahí, del sentimiento de una inminencia ${ }^{7}$.

La experiencia de la otredad, vertida en permanente aprendizaje, no es otra cosa que una experiencia verbal. Escribir es nombrar lo ausente, dar espacio a lo que no está, sabiendo que lo otro, aquello que nos precede, es siempre otro de sí. De ahí que el desplazamiento de la conciencia de sí a la ausencia del tú, el salto hacia el otro a partir de Nuevas canciones (1924), busque la identificación, más que la simple nostalgia, en la unidad del poema

$$
\mathrm{L}
$$

Con el tú de mi canción no te aludo, compañero; ese tú soy yo.

\footnotetext{
7 "La palabra básica YO-Tú funda el mundo de la relación”, afirma M. BUBER en su clásico estudio, Yo y Tú, Madrid (Caparrós Editores) 1993, p.12. En cuanto a la continua traslación de sus relaciones pronominales, pues el Yo y el Tú son a la vez reversibles y complementarios, véase el estudio de E. BENVENISTE, Problemas de lingüística general, México (Siglo XXI) 1974, 4a ed., pp.161ss. Sobre el carácter enigmático del lenguaje, que se funda en la posibilidad de su propia imposibilidad, véase el trabajo de J.M. CUESTA Abad, Poema y enigma, Madrid (Huerga y Fierro)
} 1999. 
Palabra hecha música, es decir, canción que da voz a lo otro de mí, ley o condición de lo poético. Pues la poesía se revela como un viaje de ida y vuelta, en el que la palabra desciende para ascender, para traer a la luz el sentido de una ausencia. El poeta, sostenido por la diferencia, desea ser lo otro de sí, lo irreductible. Su otredad instaura la ausencia como creación.

La ausencia llama. Fue necesaria la soledad para estar en lo otro, para que la realidad se muestre en toda su plenitud. En el soneto "Oh soledad, mi sola compañía", incluido en la sección de "Los sueños dialogados", la soledad se revela como trato con el misterio y nos da la medida de lo real

\section{IV}

¡Oh soledad, mi sola compañía, oh musa del portento que el vocablo diste a mi voz que nunca te pedía! Responde a mi pregunta: ¿Con quién hablo?

5 Ausente de ruidosa mascarada, divierto mi tristeza sin amigo, contigo, dueña de la faz velada, siempre velada al dialogar conmigo.

Hoy pienso: este que soy será quien sea;

10 no es ya mi grave enigma este semblante que en el íntimo espejo se recrea

sino el misterio de tu voz amante. Descúbreme tu rostro: que yo vea fijos en mí tus ojos de diamante.

El Otro es siempre un habitante de la más cercana lejanía ("Tengo a mis amigos / en mi soledad, / cuando estoy con ellos / ¡qué lejos están!", LXXXVI). De forma densa y concentrada, como es propio de la escritura aforística, se expresa en este proverbio, y también en el soneto, una sociología negativa de la soledad. "Pájaro solitario", por utilizar palabras de San Juan de la Cruz, difícilmente podrá el poeta producirse en tropel y acaso su aventura solitaria sea una forma de transparencia de la realidad en su plenitud, de máxima disponibilidad de la palabra. El hecho de que la soledad se muestre misteriosa al hablante ("dueña de la faz velada"), ¿no indica ya una apertura, un deseo 
de revelar lo desconocido?. En el discurso dialéctico a que se reduce el poema, la marca subjetiva de la exclamación e interrogación, el valor metafórico de los adjetivos antepuestos ("ruidosa mascarada", "grave enigma", "íntimo espejo") y el diamante como símbolo de la realidad absoluta, pues participa de la simbólica del centro irradiante, la soledad deja de ser enigmática ("el misterio de tu voz amante") y se revela como forma suprema de relación con lo desconocido, con la realidad en su plenitud. Soledades fue el primer libro de Machado y en soledad pasó toda su vida, como dijera Lope de Vega, sin salir de ella ("De mis soledades voy, / a mis soledades vengo"). En su estado de plenitud sin bordes, esa soledad es lo que abre y dilata el lenguaje, manteniéndolo abierto a cualquier posibilidad ${ }^{8}$.

El hombre es un ser esencialmente heterogéneo, un ser de diferencias, y esa heterogeneidad es lo único que verdaderamente le interesa al poeta. La intuición poética, al penetrar, por vía emotiva, la totalidad del ser, salta de lo real a lo irreal, nos hace ir de lo que somos a lo que no somos y nos remite a lo otro de uno mismo. La temática filosófica de la heterogeneidad del ser, más heraclítea que parmenídea, apuntada ya por Machado en Nuevas canciones y Los complementarios, se desarrolla a través de sus dos grandes creaciones apócrifas: Abel Martín y Juan de Mairena. Por este camino dialéctico de afirmaciones contrarias, que en su choque no dejan de complementarse, discurre De un cancionero apócrifo (1924-1936), en donde el enfrentamiento entre realidad y ficción, verdad y fantasía, es lo que da unidad a un conjunto bastante disperso. El juego de los apócrifos responde a un ejercicio de incomprensión, de pensar algo en contra de lo que se dice y oír lo otro complementario que resuena en lo dicho. Tanto la actitud erótica de Abel Martín como la más retórica de su discípulo Juan de Mairena, que se presentan a la vez como poetas-filósofos, revelan una libertad de pensamiento que se traduce en libertad de expresión. En ambos casos, a los que hay que añadir el tercer apócrifo no realizado Pedro de Zúñiga, pues en el origen de la construcción apócrifa hay una coexistencia triádica, la noción de apócrifo va ligada a lo que Machado llama la "fe poética", es decir, a la posibilidad de la imaginación poética para descubrir realidades que permanecen ocul-

${ }^{8}$ Aludiendo al doble significado de la soledad, conciencia de sí y deseo de salir de sí, O. PAZ ha señalado: "El hombre es nostalgia y búsqueda de comunión. Por eso cada vez que se siente a sí mismo se siente como carencia de otro", en su ensayo "La dialéctica de la soledad", que figura como apéndice de su estudio, El laberinto de la soledad, México (FCE) 1980, $8^{\text {a }}$ reimpr., pp.175-191. Para la etapa final de Machado, tengo en cuenta el estudio de su hermano J. MACHADO, Últimas soledades del poeta Antonio Machado, Soria (Imprenta Provincial) 1970. 
tas. En este sentido, el pensar apócrifo tiene un claro sentido utópico, reconocido en su potencialidad siempre anticipadora, que alimenta los últimos años del poeta y se proyecta en una triple dimensión: erótica, poética y dramática, tanto en verso como en prosa.

Respecto a la primera, la pretensión de lo objetivo como forma de alcanzar lo real, se revela como sed que nos llama, como ausencia que nos mantiene abiertos ("El Eros martiniano sólo se inquieta por la contemplación del cuerpo femenino, y a causa precisamente de aquella diferencia irreductible que en él advierte. No es tampoco para Abel Martín la belleza el gran incentivo del amor, sino la sed metafísica de lo esencialmente otro", afirma Machado). A la luz de de esta reflexión se hace visible el fondo de esta copla

Gracias, Petenera mía:

en tus ojos me he perdido;

era lo que yo quería.

La pérdida engendra el deseo. Por los ojos de la amada el amante sale de sí mismo. El hombre, más que un ser racional o lingüístico, es un ser erótico. El amor, que necesita de la muerte para su cumplimiento, crea para no morir. Aprendizaje donde perder es ganar, opción mística y poética. Escribir, como morir, es abrir. El poeta escribe para dejar abierto un vacío, para dar acogida a lo imposible en el poema, pues acoger es dejar que lo otro se abra en uno. En el límite del poema, experiencia de la unidad, la apertura se hace hospitalidad, el otro revela lo propio. Mas al Otro sólo podemos conocerlo por amor, afectivamente, después que la amada ha desaparecido. El olvido es una forma de amor sublimado. En una de las "Canciones a Guiomar" nos dice el poeta: "Escribiré en tu abanico: / te quiero para olvidarte, / para quererte te olvido". En esos tres versos aparece condensada la teoría amorosa de Machado. El olvido es pérdida, pero en esa pérdida habita la melancolía. Olvidar es intentar que el dolor de la separación no hubiera sucedido, la ilusión de una victoria sobre el tiempo. El poeta bucea en las aguas del olvido para fijar la imagen del reconocimiento .

${ }^{9}$ La ausencia despierta el deseo del otro. Refiriéndose al objeto amado del sujeto amoroso, señala R. BARTHES, Fragmentos de un discurso amoroso, México (Siglo XXI) 1982, p.45: "Ahora bien, no hay ausencia más que del otro: es el otro quien parte, soy yo quien me quedo". En cuanto a la construcción triádica de los apócrifos machadianos, véase el artículo de H. LAINTENBERGER, "Los apócrifos de Machado: consideraciones preliminares a una explicación coherente", Ínsula, 506507, febrero-marzo 1989, pp.45-46. Merece también destacarse el ensayo de A. 


\section{Armando López Castro}

La escisión entre el sentimiento y la razón, que representa la crisis de la burguesía desde finales del siglo XIX, trae como consecuencia la búsqueda de una expresión colectiva que deja superada la expresión individual. Abel Martín es un poeta solitario que pertenece al pasado ("Calló el poeta, el hombre solitario, / porque el aire del cielo aterecido / le amortecía el fino estradivario", se dice en la composición última de su Cancionero apócrifo), mientras el porvenir es para el poeta cordial que canta con todos ("Cuando el sentimiento acorta su radio y no trasciende del yo aislado, acotado, vedado al prójimo, acaba por empobrecerse y, al fin, canta de falsete. Tal es el sentimiento burgués, que a mí me parece fracasado; tal es el fin de la sentimentalidad romántica. En suma, no hay sentimiento verdadero sin simpatía, el mero pathos no ejerce función cordial alguna, ni tampoco estética. Un corazón solitario -ha dicho no sé quién, acaso Pero Grullo- no es un corazón; porque nadie siente si no es capaz de sentir con otro, con otros...ipor qué no con todos?", escuchamos en el Diálogo entre Juan de Mairena y Jorge Meneses).

Según esto, el invento de La máquina de trovar, recurso dramático que trata "de obtener una expresión colectiva, de grupo", responde a la pretensión objetiva, completamente ilusoria, de eliminar lo individual del poema, que se fundamenta en la universalización de lo cualitativo. Para Mairena, no el profesor de retórica, sino el poeta-filósofo del Cancionero apócrifo, autor del libro de poesías Coplas mecánicas y que "había imaginado" a Meneses, la preferencia por lo irreal (partir siempre de lo imaginado, de lo supuesto, de lo apócrifo, nunca de lo real", aconseja a sus discípulos), engendra la posibilidad de alcanzar algo mejor, de ahí la actitud escéptica y el tono irónico, que impiden al pensamiento descansar en ningún punto fijo y destruyen todo aquello que podría suscitar la ilusión de definitivo. Lo que hace la ironía, forma de lo apócrifo, es destruir cualquier espejismo de certeza, penetrar las apariencias, dejar que lo oculto se manifieste ("Por debajo de lo que se piensa está lo que se cree, como si dijéramos en una capa más honda de nuestro espíritu. Hay hombres tan profundamente divididos consigo mismos, que creen lo contrario de lo que piensan", afirma el pedagogo Mairena al comienzo del capítulo XXXIII). La destrucción de lo evidente por lo oculto, característica de lo apócrifo, es lo que subyace en la copla repetida por Martín, Mairena y Machado

\section{Confiamos}

SALVADOR JOFRÉ, "La erótica en Antonio Machado", en Homenaje a Machado, Málaga (Diputación de Málaga) 1985, pp.85-99. 
en que no será verdad

nada de lo que pensamos.

La construcción hiperbática de esta condensada soleá sirve para contraponer dos niveles de conciencia: el afectivo ("Confiamos") y el racional ("pensamos"), destacando el primero sobre el segundo. El poeta sabe de una experiencia más honda, la poética, por eso prefiere el camino oblicuo de la ironía, cuya función es irrumpir súbitamente sobre lo discursivo y racional, dar a luz, engendrar otros sentidos posibles. De ahí que la ironía apunte a la desocultación y se empareje con el misterio como fuente de lo poético. El poema, con su desvelamiento instantáneo, borra lo ya dicho y nos hace otros. El radical escepticismo de Mairena es signo de su fluidez creadora ${ }^{10}$.

La vida de Machado en Segovia (1919-1925) fue muy distinta al retiro solitario de Baeza. La convivencia en tertulias, como la que se reunía en el taller del ceramista Fernando Arranz, a la que acudían, entre otros, el profesor Blas Zambrano y el escultor Mariano Barral, las colaboraciones en periódicos y revistas, sobre todo en la Revista de Occidente a partir de su fundación en julio de 1923, y de modo especial sus constantes viajes a Madrid, donde presencia el declive político-social y las nuevas inquietudes artísticas de las vanguardias, dan un nuevo rumbo a su vida. Sin embargo, dentro del panorama cultural del momento, caracterizado por el contraste entre el elitismo y el neohumanismo, tal vez sea la necesidad de comunicar con el prójimo, visible en el reconocimiento del Otro, el antidogmatismo y la sentimentalidad compartida, lo que orienta a Machado hacia la segunda de las concepciones. Fruto de esa inclinación cordial, basada en el diálogo, es la colaboración para el teatro, con su hermano Manuel, que se extiende de 1926 a 1932, época en la que Valle-Inclán realiza el viraje del modernismo al esperpento, y que, a pesar de sus limitaciones, casi nula relación con los problemas del momento, desplazamiento hacia el pasado y verso escasamente dramático, pone en escena lo que es característico de la creación apócrifa: la imposibilidad de ser, la necesidad de mantener en movimiento "ese voletío de la imaginación", co-

${ }^{10}$ Para la conciliación de la aparente inconciliabilidad de los apócrifos, que niegan el mundo vivido para crear otro posible y mejor, véase el estudio de E. BAKER, La lira mecánica. En torno a la prosa de Antonio Machado, Madrid (Taurus) 1986, en donde se ofrece, además, un análisis de La máquina de trovar, a la luz de la teoría hermética, vigente en esos años. En cuanto a la prosa de Juan de Mairena, abierta a la universalidad del pensamiento, tengo en cuenta el trabajo de Pablo de A. COBOS, El pensamiento de Antonio Machado en Juan de Mairena, Madrid (Ínsula) 1971. 
mo dice el gitano Pedro Cifuentes en La duquesa de Benamejí, para extraer de lo oculto lo posible no realizado e inventar algo distinto.

En arte lo esencial es actuar como si se creyera. Ya había dicho Shakespeare, de cuyo soneto CXXXVIII hace Machado una importante glosa, "El poeta más verdadero es el más fingidor". Y este sentido ficticio de la experiencia artística, pues el arte vive de una duplicidad entre la apariencia y la realidad, recorre por entero el teatro de los Machado, en donde el mundo real es iluminado cuando se le proyecta sobre la función de la posibilidad. Sus dos obras más celebradas, $L a$ Lola se va a los puertos y El hombre que murió en la guerra, además de reproducir viejos motivos machadianos, como la dualidad idealismo-realismo, la polaridad arte-vida, la frontera entre el sueño y el despertar, nos fascinan no por lo creíble, sino por lo increíble, por el efecto de ilusión, característico de la obra dramática. Si tenemos en cuenta que los Machado llegan al teatro en plena madurez artística y son ya conocidos del público lector, no sorprende que sus obras dramáticas pongan en escena el problema de la relación con el otro y que los personajes quieran vivir otra vida distinta. Refiriéndose a la renovación del teatro, declara Mairena: "Los grandes poetas de la escena supieron esto mejor que nosotros; ellos no limitaron nunca la palabra a la expresión de cuantas naderías cambiamos en pláticas superfluas, mientras pensamos en otra cosa, sino que dicen también esa otra cosa, que suele ser lo más interesante", XXI). Esta virtualidad de la expresión dramática, pues lo real nos ha sido dado como simulacro, tiende a identificar sujeto y objeto bajo el principio igualitario de la ilusión. Para la inasible y huidiza Lola, trasunto ideal de Guiomar ("El propósito de sublimar a la Lola es cosa mía. Se me ocurrió a mí pensando en mi diosa y se exponía en la primera escena del segundo acto que te leí un día en nuestro rincón. A ti se debe, pues, toda la parte trascendente e ideal de la obra", confiesa Machado en una de las Cartas a Guiomar), la vida sólo es verdad mientras se canta y se toca

\section{LOLA: El querer y el olvidar del cante, ya es otra cosa. Eso es verdad, por lo menos mientras se canta y se toca}

de manera que el arte de la 'cantaora', que consiste en "echar al viento el corazón", es ilusión, juego con la realidad, manteniendo abierta la alteridad de las formas. Dado que "la Lola no es de este mundo", renunciará a todo "querer particular" y embarcará para América. Sólo lo 
que excede la realidad puede superar la ilusión de la realidad, por eso los sueños y las ilusiones de la "cantaora" dependen paradójicamente de su imposible realización. En este sentido, la Lola es una creación eminentemente apócrifa.

Frente al idealismo de la Lola, Juan de Zúñiga aspira a realizar el ideal de "los hijos de nadie" en El hombre que murió en la guerra, asumiendo, bajo la máscara, la personalidad apócrifa del hospiciano Miguel de la Cruz y conjurando el fantasma de la guerra mediante el amor fraternal. Aunque el deseo de encuentro con el otro supone para Juan un rechazo de lo ideal, al final del último acto Juan reconoce ante Guadalupe que el mundo de los hijos de nadie ("Nadie es más que nadie", recuerda el refrán popular), es algo ilusorio e imposible de realizar: El hombre es un animal un poco absurdo; ha inventado la lógica, pero ha vivido siempre de ilusiones. Cada tiempo tiene las suyas.

Así pues, no es posible vivir sin soñar, sin llevar una máscara o representar un papel. El problema de la doble personalidad, unido al tema del apócrifo, pues Lola, Juan y Pedro de Zúñiga nacen en 1928, y reiterado en todas las obras dramáticas de los Machado, responde a una visión de lo poético como plenitud de conciencia ("Si vivir es bueno, / es mejor soñar, / y mejor que todo, / madre, despertar", dice el cantar LXXXI de Campos de Castilla). Situado en la frontera entre dos mundos, nostálgico de lo real y buscador del otro real, Machado hizo de la creación apócrifa la forma misma de su poetizar, dejando su propio deseo en suspenso y devolviendo su sentido radical a la ilusión. La indistinción de lo verdadero y lo falso, de lo real y lo irreal, se ofrece, desde el fondo del sueño, como virtualidad más allá de lo real, como presentimiento de una trascendencia que lo habita ${ }^{11}$.

Durante las etapas de Baeza y Segovia, entre 1912 y 1929, se había producido en Machado una superación del 98, pasando de un solipsismo, de carácter metafísico, a una apertura al tú, a lo social e his-

${ }^{11}$ Refiriéndose a los personajes femeninos de las historias amorosas, señala C. OLIVA: "Ellas, sobre todo, son seres, de tan perfectos, imposibles. Lola es una estupenda imposibilidad. No es real. Su reino no es de este mundo. Y por eso quizá se vaya a América", en su ponencia, "El teatro de los Machado, medio siglo después", en Antonio Machado hoy, Sevilla (Alfar) 1990, Tomo I, p.55. Sobre el teatro de los Machado, pueden verse, entre otros, los estudios de M.H. GUERRA, El teatro de Manuel y Antonio Machado, Madrid (Mediterráneo) 1966; y A. ROMERO FERRER, Los hermanos Machado y el teatro (1926-1932), Sevilla (Diputación de Sevilla) 1996. Respecto a la creación apócrifa, remito al ensayo de E. BARJAU, "El tema del apócrifo en el teatro de los hermanos Machado", en Antonio Machado: teoría y práctica del apócrifo, Barcelona (Ariel) 1975, pp.123-149. 
tórico, de signo utópico. De 1931 proceden dos textos importantes: "Proyecto de un discurso de ingreso en la Academia de la Lengua", que trasluce la serie de lecturas que están detrás de su poesía; y "El mañana", esbozo destinado a posteriores reflexiones sobre el diálogo y el otro como prójimo. Frente a la metafísica del individualismo racionalista, que ha animado el siglo XIX, Machado percibe claramente la constitutiva alteridad del ser: Sólo Platón y Cristo supieron dialogar, porque ellos más que nadie creyeron en la realidad espiritual de su prójimo. El ochocientos, en cambio, se mostró en lo profundo, incapaz para el diálogo, lo que explica el carácter idolátrico de su lírica. Su pensamiento parte siempre del yo para tornar a él. Ninguna de sus metafísicas implica la realidad irreductible y absoluta del tú. Esto es lo que quería decir mi apócrifo Juan de Mairena cuando afirmaba que el hombre del ochocientos no creyó seriamente en la existencia de su vecino.

La relación paradójica entre identidad y alteridad, que se afirma en la singularidad y la diferencia, implica la convergencia de dos conciencias integrales y complementarias, que dialogan juntas, como don Quijote y Sancho. Frente al predominio de la identidad en el ochocientos, que conduce a la enajenación del prójimo, Machado reclama un pensamiento de la alteridad en relación y comunión. De ahí su creciente interés por la figura de Cristo, el otro de Dios, desde la ausencia en sus Poesías hasta su presencia en Abel Martín y Juan de Mairena, intensificada después de la lectura Del sentimiento trágico de la vida, de su maestro Unamuno, cuyo título originario era Tratado sobre el amor de Dios. Para Machado, la clave de la metafísica cristiana, abolida por el pensamiento idealista, reside en Dios mismo como Hijo y Espíritu, en la relación originaria del amor compartido ${ }^{12}$.

Juan de Mairena no fue inmune al revulsivo de la guerra civil ("un gran avivador de conciencias adormiladas", según escribe en octubre de 1938), y siendo un hombre de diálogo, su inclinación metafísica fue cediendo al realismo de la causa del pueblo, cuya memoria viva se toca casi religiosamente en las poesías y prosas de la guerra. En cuanto a los escritos en prosa, tal vez habría que destacar el corto ensayo "Sobre una lírica comunista que pudiera venir de Rusia", pu-

${ }^{12}$ El interés de Machado por la figura de Cristo se debe al clima de general reacción que se da contra el idealismo en el decenio de 1920 a 1930, según revelan los escritos de Bergson y Husserl. En este sentido, pueden verse los artículos de A. SÁNCHEZ BARBUDO, "El impulso hacia el otro y hacia lo otro", en El pensamiento de Antonio Machado, Madrid (Guadarrama) 1976, pp.11-23; y J.L. ABELLÁN, "El mito de Cristo en Antonio Machado", en Mito y Cultura, Madrid (Seminarios y Ediciones) 1971, pp.43-97. 
blicado en la revista Octubre en 1934, y en el que la pregunta de Juan de Mairena ("¿Cabe una comunión cordial entre hombres, que nos permita cantar en coro, animados de un mismo sentir?"), nos habla ya de una poesía que sea expresión del sentimiento colectivo. Por eso, se siente unido a los milicianos, cuyas caras le obsesionan desde el principio de la guerra, porque luchaban y morían por un ideal. La decisión de jugarse la vida por una causa ("ponen al tablero su vida por su ley"), con el recuerdo al fondo de Jorge Manrique, es lo que les da un aire de trágica nobleza. La tradicional lucha del "pueblo" contra los "señoritos", que Machado ve ya iniciada en el Poema del Cid, subyace en la elegía dedicada a Lorca, víctima del cainismo secular

\section{EL CRIMEN FUE EN GRANADA}

\section{I \\ EL CRIMEN}

Se le vio, caminando entre fusiles, por una calle larga, salir al campo frío, aún con estrellas, de la madrugada.

5 Mataron a Federico cuando la luz asomaba. El pelotón de verdugos no osó mirarle la cara. Todos cerraron los ojos; 10 rezaron: ¡ni Dios te salva! Muerto cayó Federico -sangre en la frente y plomo en las entrañas. ...Que fue en Granada el crimen sabed -ipobre Granada!-, en su Granada...

\section{II}

\section{EL POETA Y LA MUERTE}

15 Se le vio caminar solo con Ella, sin miedo a su guadaña. -Ya el sol en torre y torre; los martillos en yunque -yunque y yunque de las fraguas. Hablaba Federico,

20 requebrando a la muerte. Ella escuchaba. 
"Porque ayer en mi verso, compañera, sonaba el golpe de tus secas palmas, y diste el hielo a mi cantar, y el filo a mi tragedia de tu hoz de plata,

25 te cantaré la carne que no tienes, los ojos que te faltan, tus cabellos que el viento sacudía, los rojos labios donde te besaban... Hoy como ayer, gitana, muerte mía, 30 qué bien contigo a solas, por estos aires de Granada, ¡mi Granada!”.

\section{III}

Se le vio caminar...

Labrad, amigos, de piedra y sueño, en el Alhambra,

35 un túmulo al poeta, sobre una fuente donde llore el agua, y eternamente diga: el crimen fue en Granada, ¡en su Granada!

Desde el período alejandrino hasta la poesía moderna, pasando por su consolidación en la época romana, la elegía es un género abierto que trata de expresar el yo lírico de la experiencia. La indignación del yo poético ante el crimen del poeta admirado hace que su discurso trascienda la simple lamentación para convertirse en reconocimiento del otro complementario. Por eso, las cuatro partes del esquema elegíaco, presentación del acontecimiento, lamentación, panegírico y consolación directa, quedan aquí reducidas a tres: relato del crimen, diálogo del poeta con la muerte y recuerdo del poeta asesinado. Como es propio de los poemas elegíacos, la entonación épica, el ritmo irregular y el lenguaje afectivo se asocian lingüísticamente para revelar una actitud humana ante el otro, un deseo de colectivización. Si dejamos a un lado el tono épico y el ritmo irregular, subrayados gráficamente mediante la exclamación y el uso del guión o paréntesis, que rompen la entonación del discurso e introducen el punto de vista del hablante, y nos fijamos en el lenguaje, observamos, a nivel fónico, un predominio de la asonancia $a-a$ como eco de Granada, que ocupa siempre un lugar clave en el poema; morfológicamente, hay que destacar la presencia de vocativos ("compañera", "gitana", "muerte mía") y la reiteración anafórica de verbos deliberadamente impersonales 
("Se le vio caminando", "Se le vio caminar"), que abren cada una de las tres partes, rasgos que dan al discurso un matiz apelativo e intensifican un mismo sentimiento de muerte; sintácticamente, la presencia de un discurso polimórfico, que combina el discurso indirecto, propio de un testigo o narrador impersonal en la primera parte, con el discurso directo del monólogo en la segunda, moviéndose desde los registros del habla coloquial (" $i n i$ Dios te salva!") hasta las resonancias intertextuales del poeta evocado. De ahí que tal vez sea el análisis semántico el que mejor revela el grado de asimilación de la poesía lorquiana por parte de Machado. De las distintas imágenes utilizadas, caracterizadas por su sobriedad y fácilmente reconocibles, como el sonido de los martillos y los yunques, que ya aparece en el poema "El emplazado", o el encuentro de Federico con la muerte, ya poetizado en la "Canción de la muerte pequeña", acaso sea necesario fijarse en dos de ellas, que se muestran en la parte final del poema: el túmulo de "piedra y sueño", en donde la combinación de lo real y lo irreal, de materialidad y ensoñación, presente en el Llanto por la muerte de Ignacio Sánchez Mejías, revela el núcleo mismo de la poética lorquiana: la capacidad de presentar lo imaginario como real; y la función simbólica del agua, de tanta resonancia en la lírica machadiana, en su doble papel de llorar al muerto y de denunciar el crimen. El sentimiento de haber perdido algo valioso, un joven poeta en pleno proceso creador, es lo que lleva a Machado a hacer suya la trágica muerte de Lorca, incorporando todo ese ciclo de muerte-resurrección, tan persistente en su escritura, pues dar figura a la muerte, hacerla representable, es una forma de humanizar lo real ${ }^{13}$.

La creación literaria no es ajena a la experiencia vital. La escritura, en cuanto forma de identidad, nos permite tomar conciencia de que somos ajenos a nosotros mismos. Separados de la Unidad originaria, nuestro yo queda expuesto a la erosión del tiempo y a la unilateralidad de lo racional. Dentro de la poesía moderna, la famosa cita de Rimbaud ("Je est un autre"), asimilada por Pessoa y Machado, pensadores

${ }^{13}$ En alusión a la envidia de los granadinos ante el éxito y el genio de Lorca, su amigo Luis ROSALES declara: "Y además, Federico fue muerto por la envidia. España es un país donde los frutos de la celebridad están envenenados. La fama no aporta ni dinero ni consideración, ni ventajas de ningún tipo, únicamente la envidia más sórdida", testimonio recogido por M. AUCLAIR en su estudio, Enfances et mort de García Lorca, París (Seuil) 1968, p.386. En cuanto a la interpretación del poema, uno de los más analizados por la crítica, pueden verse, entre otros, los comentarios de $\mathrm{M}$. ALONSO, Antonio Machado. Poeta en el exilio, Barcelona (Anthropos) 1985, pp.2931; y K. VIDACOVICH PETROV, "La poesía de Antonio Machado y la guerra civil", en Antonio Machado hoy, Sevilla (Alfar) 1990, Vol.I, pp.567-572. 


\section{Armando López Castro}

de la heterogeneidad, revela que el Otro no sólo nos completa, sino que fundamentalmente nos constituye. En plena madurez literaria, Machado acertó a pensar "la esencial heterogeneidad del ser" y a encontrar, en la experiencia compartida de la alteridad, una relación interpersonal "sin la cual no se pasa del yo al tú". Apoyándose en el giro dialógico del pensamiento moderno, del que son hitos fundamentales nociones como la del respeto al otro en la filosofía moral de Kant, el reconocimiento del otro en la filosofía política de Hegel y el rostro del otro de Lévinas, formado en la estela de Husserl, Machado otorga un papel central a la projimidad o relación concreta con el otro como vía no sólo para la constitución del sujeto, sino también como vía de reafirmación colectiva. A esa universalidad sólo se llega si la escritura es capaz de integrar nuestras diferencias. El proverbio de la relación entre el poeta y su mundo ("No es el yo fundamental / eso que busca el poeta, / sino el tú esencial"), que exige una réplica por parte del lector ("No, no es tu yo accidental / eso que en ti voy buscando: / es tu yo esencial"), pone de manifiesto una filosofía de la intersubjetividad, una relación antes del contacto, pues el otro viene a ser una ratificación de lo que cada uno ya era. A partir de Nuevas canciones (1924), el otro, el próximo o el prójimo, irrumpe en la escritura de Machado en su irreductible particularidad, denunciando, en su aparición inmediata, todo lo que la ideología oculta. El reencuentro con el otro, bajo las formas irónicas de la máscara o el doble, entraña el enigma de la realidad, a la que, según Machado, no se accede sino por vía poética ${ }^{14}$.

La poesía busca lo absoluto, la verdad última, la revelación, otra realidad superior que permite aceptar el lado oscuro del mundo en donde el creador está inmerso. La creación poética implica la alteridad, la máscara, pues la máscara revela siempre. La referencia al desdoblamiento, que forma parte de la crisis de identidad finisecular y se

${ }^{14}$ Respecto a la metafísica de la otredad, señala J.M ${ }^{a}$ VALVERDE: "Ya es sabido en qué consiste esa otredad: en poner en la misma entraña del ser una esencial heterogeneidad, un desdoblarse, un querer ser lo que no se es", en su ensayo "Evolución del sentido espiritual de la obra de Antonio Machado", incluido en Estudios sobre la palabra poética, Madrid (Rialp) 1952, pp.117-118. Sobre la noción de otredad como centro de la poética machadiana, remito al ensayo de J. MALPARTIDA, "Antonio Machado y Octavio Paz: hacia una poética de la otredad", en La perfección indefensa, México (FCE) 1998, pp.31-39. Desde el punto de vista moral, el nuevo pensamiento del otro como "crisis de la modernidad" ha sido analizado por G. BELLO, La construcción ética del otro, Oviedo (Ediciones Nobel) 1977. En cuanto al uso de pseudónimos o personajes-máscara, que incide en el fenómeno de la crisis de identidad y de la que participan los apócrifos de Machado y los heterónimos de Pessoa, véase el estudio de A. APOLINÁRIO LOURENÇO, Identidad y alteridad en Fernando Pessoa y Antonio Machado, Universidad de Salamanca 1997. 
integra en el contexto de la poesía simbolista, implica la existencia del otro que se apodera del yo, de otra voz distinta a la de uno mismo, que nos busca para nombrarnos. La otredad consiste en un estado de recepción, previo al decir, donde el poeta se convierte en un medio físico, en un transmisor, a través del cual se hace oír la voz del otro, pues cuando la palabra poética pierde esta condición mediadora, se trivializa y desaparece como tal. El yo contemplado se exterioriza, se hace otro, lo que quiere decir que el ensimismamiento y la alteridad, los dos anversos del ser, forman parte de un mismo proceso. Ya en el poema "Retrato", de Campos de Castilla, aparece la idea de la duplicidad de la conciencia humana ("Converso con el hombre que siempre va conmigo / -quien habla solo espera hablar a Dios un día-; / mi soliloquio es plática con este buen amigo / que me enseñó el secreto de la filantropía"). Después, en un texto de Los complementarios, cuaderno de apuntes que el autor fue redactando en Baeza entre 1912 y 1925, la poética de la otredad conlleva una orientación dialógica del discurso ("Mi sentimiento no es, en suma, exclusivamente mío, sino más bien nuestro. Sin salir de mí mismo, noto que en mi sentir vibran otros sentires, y que mi corazón canta siempre en coro, aunque su voz sea para mí la voz mejor timbrada. Que lo sea también para los demás, éste es el problema de la expresión lírica"). Por último, este impulso hacia lo otro es lo que llevará a Machado a la creación del apócrifo Abel Martín y de su "discípulo y contradictor" Juan de Mairena, que confirman la metafísica y la poética de Antonio Machado. La poética de Mairena, producto, en gran parte, del diálogo de Machado con pensadores contemporáneos, como Unamuno, Ortega, Bergson y Heidegger, y visible en los textos posteriores a 1934, muestra una concepción del lenguaje poético, próximo a lo real inmediato, que está en disonancia con la estética de las vanguardias. El intento de "hacerse comprender por las mismas piedras de la calle" pone de relieve la cuestión de la alteridad en torno a la expresión poética, la cual, a pesar de su falta de sistematización y coherencia, muestra un proceso de creciente despersonalización, de complicidad del yo con el otro, en el que "lo otro no se deja eliminar". Dentro de esa complementariedad, que parece atravesar la escritura última de Machado, la invención apócrifa no hace más que multiplicar poéticamente las formas de relación con lo real. La otredad traduce así una visión integral, una búsqueda de lo absoluto, propia de la palabra poética. 